\title{
Monitoring Jarak Tempuh Lari Menggunakan Sensor Accelerometer
}

\author{
Mochamad Arifin ${ }^{* 1}$, Wahyu Andhyka Kusuma ${ }^{2}$, Syaifuddin ${ }^{3}$ \\ 1,2,3 Teknik Informatika/Universitas Muhammadiyah Malang \\ Mochamad.arifin7@gmail.com ${ }^{* 1}$, kusuma.wahyu.a@gmail.com²
}

\begin{abstract}
Abstrak
Berlari merupakan frekuensi langkah yang dipercepat sehingga pada waktu berlari terdapat kecenderungan badan melayang. Pada saat berlari kedua kaki tidak menyentuh sekurang-kurangnya satu kaki tetap menyentuh tanah. Seiring perkembangan teknologi yang semakin pesat dan maju, untuk mengukur suatu percepatan ketika berlari dapat menggunakan teknologi accelerometer. Accelerometer dapat digunakan sebagai alat bantu manusia yang memiliki beberapa kelebihan terutama untuk pengecekan percepatan dan jarak tempuh. Selain itu, accelerometer digunakan untuk mengukur percepatan, mendeteksi getaran, dan bisa juga untuk percepatan gravitasi. Pendeteksian gerakan berdasarkan pada 3 sumbu yaitu kanan-kiri, atas-bawah dan depan-belakang. Pada penelitian ini, besaran akselerasi pada sumbu $x, y$, dan $z$ dari sensor accelerometer dengan menggunakan parameter jarak meliputi 5 meter, 10 meter, 15 meter dan 20 meter. Dari hasil pengujian yang diperoleh sebanyak 5 responden maka dapat diambil kesimpulan bahwa kecocokan data pengujian yang diambil secara manual dengan aplikasi memiliki perbedaan. Dari jarak pengujian 5 meter diperoleh hasil galat presentase error sebanyak 7,96\%. Jarak 10 meter diperoleh sebanyak 6,4\%. Jarak 15 meter diperoleh 13,68\% meter. Selanjutnya, jarak 20 meter yaitu $11 \%$. Pengujian dilakukan dengan menggunakan aplikasi monitoring pada smartphone yang telah terinstall dan diletakkan pada saku celana responden sehingga akan diperoleh nilai data pada sumbu $x$,y dan $z$ pada aplikasi yang kemudian di konversikan pada grafik gelombang sinus dan perhitungan manual berupa perhitungan jarak dan galat presentase error.
\end{abstract}

Kata Kunci: Sensor Accelerometer, Monitoring, Jarak Tempuh Lari, MIT App Invertor, Berlari

\begin{abstract}
Running is an accelerated frequency of steps so that when running there is a tendency for the body to float. When running both feet do not touch at least - one foot still touches the ground. Along with the development of technology that is increasingly rapid and advanced, to measure an acceleration when running can use the accelerometer technology. Accelerometer can be used as a human aid which has several advantages, especially for checking acceleration and mileage. In addition, the accelerometer is used to measure acceleration, detect vibrations, and can also be used for accelerating gravity. Motion detection is based on 3 axes namely right-left, top-bottom and front-back. In this study, the amount of acceleration on the $x, y$, and $z$ axis of the accelerometer sensor using distance parameters includes 5 meters, 10 meters, 15 meters and 20 meters. From the test results obtained as many as 5 respondents, it can be concluded that the suitability of the test data taken manually with the application has a difference. A distance of 10 meters was obtained as much as 6.4\%. A distance of 15 meters obtained $13.68 \%$ meters. Furthermore, the distance of 20 meters is $11 \%$. The test is done by using a monitoring application on a smartphone that has been installed and placed in the pocket of the respondent's pants so that the data values on the $x, y$ and $z$ axes in the application are then converted to a sine wave graph and manual calculations in the form of distance and error percentage errors.
\end{abstract}

Keywords: Accelerometer Sensor, Monitoring, Running Mileage, MIT App Invertor, Running

\section{Pendahuluan}

Semakin berkembangnya ilmu pengetahuan dan teknologi, semakin banyak inovasi terbaru yang muncul dalam berbagai ilmu. Olahraga yang dapat dilakukan sehari-hari dengan mudah yaitu olahraga lari. Berlari merupakan frekuensi langkah yang dipercepat sehingga pada waktu berlari terdapat kecenderungan badan melayang. Jadi, berlari merupakan gerakan tubuh dimana pada suatu saat semua kaki tidak menginjak tanah (ada saat melayang di udara) berbeda 
dengan berjalan yang salah satu kaki tetap harus ada yang kontak dengan tanah [1]. Seiring perkembangan teknologi yang semakin pesat dan maju, untuk mengukur suatu percepatan ketika berlari dapat menggunakan teknologi accelerometer. Pendeteksian berdasarkan 3 sumbu yaitu sumbu $x, y$ dan $z$.

Accelerometer dapat digunakan sebagai alat bantu manusia yang memiliki beberapa kelebihan terutama untuk pengecekan percepatan dan jarak tempuh. Selain itu, accelerometer digunakan untuk mengukur percepatan, mendeteksi getaran, dan bisa juga untuk percepatan gravitasi [2]. Penelitian yang dilakukan oleh Fitriani, menjelaskan bahwa pada Sistem Monitoring Langkah Kaki Dengan Menggunakan Sensor MPU6050 Berbasis Android menggunakan alat yaitu gyroscope dari sensor MPU6050 [3]. Gyroscope berfungsi untuk mengukur atau menentukan orientasi suatu benda berdasarkan pada ketetapan momentum sudut. Penelitian ini telah dilakukan pengujian dengan berjalan kaki dengan jumlah langkah yang berbeda. Pengujian alat tersebut dilakukan oleh 1 orang penguji [4]. Sudut yang dipakai pada pengolahan data adalah nilai dari sumbu $X$ yang dikonversikan kedalam bentuk grafik gelombang sinus [3].

Oleh karena itu, pada penelitian ini penulis akan melakukan pembaharuan dengan monitoring pada jarak tempuh lari. Parameter jarak tersebut merupakan parameter awal yang dapat digunakan penelitian selanjutnya untuk menentukan analisis dari monitoring dengan menggunakan sensor accelerometer. Adapun tujuan dari penelitian tersebut, penulis akan melalukan penelitian dengan Tugas Akhir yang berjudul "Monitoring Jarak Tempuh Lari Menggunakan Sensor Accelerometer".

\section{Metode Penelitian}

\subsection{Penelitian Sebelumnya}

Penelitian yang dilakukan oleh Sabrina menjelaskan mengenai pembaruan sistem dengan Pengembangan Sistem Monitoring Langkah Kaki Dengan Sensor MPU6050 Untuk Menghitung Jumlah Penurunan Berat Badan Berbasis Android dengan meningkatkan akurasi sistem monitoring langkah kaki dan menambahkan fitur berupa waktu dan fitur untuk menghitung jumlah pembakaran kalori beserta jumlah penurunan berat badan berdasarkan jumlah langkah kaki yang diperoleh. Pada penelitian tersebut menggunakan sensor MPU6050 untuk menghitung jumlah penurunan berat badan dan gyroscope sebagai penghitung jumlah pembakaran kalori serta jumlah penurunan berat badan berdasarkan langkah kaki [4].

\subsection{Analisis Dan Perancangan Sistem}

Pada tugas akhir ini dilakukan monitoring analisis sistem untuk mengetahui jarak tempuh lari menggunakan sensor accelerometer dengan tujuan hasil yang didapat sesuai atau tidak antara data real dengan data yang didapat dari aplikasi. Untuk sensor accelerometer yang telah tertanam pada handphone penguji dilakukan penelitian lebih lanjut dengan mengolah data dari hasil pengujian dengan menghitung threshold dan menghitung hasil galat presentase error. Pergerakan sumbu yang digunakan pada penelitian ini, yaitu sumbu x, y dan z. Smartphone yang digunakan untuk pengujian sudah terdapat aplikasi monitoring jarak tempuh lari yang telah menggunakan sensor Accelerometer. Smartphone tersebut dimasukkan pada saku celana responden.

\subsection{Penerapan Metode yang digunakan}

Pada penelitian yang dilakukan oleh Sabrina (2018) telah didapatkan rumus untuk menghitung jarak yang ditempuh saat berjalan kaki, yaitu Jarak = Jumlah Langkah ${ }^{*} 0,78 m$ [4]. Metode pengujian yang digunakan untuk penelitian ini berupa metode thresholding. Data dari hasil pengujian dengan aplikasi dan dilakukan perhitungan nilai ambang batas thresholding dan ditemukan nilai dari galat presentase error [5]. Data yang diperoleh akan dikonversikan ke grafik gelombang sinus untuk memudahkan dalam melakukan penentuan nilai ambang batas [6]. Jika perubahan data sudutnya melebihi nilai titik atas dan nilai titik bawah maka disebut threshold above dan ketika perubahan data sudutnya melebihi nilai batas titik atas, sedangkan threshold below ketika perubahan nilai sudut bawah melebihi batas titik bawah [7][8][9].

\subsection{Desain Perancangan Sistem}

Pada desain perancangan sistem, penulis menggunakan aplikasi MIT APP Inventor. Aplikasi android dirancang agar dapat memonitoring pergerakan sumbu $\mathrm{x}, \mathrm{y}$, dan $\mathrm{z}$ dengan menggunakan sensor accelerometer pada smartphone yang digunakan responden. Berikut

REPOSITOR, Vol. 2, No. 6, Juni 2020: 795-802 
merupakan halaman utama aplikasi yang akan dibuat akan ditampilkan pada Gambar 1 sebagai berikut.
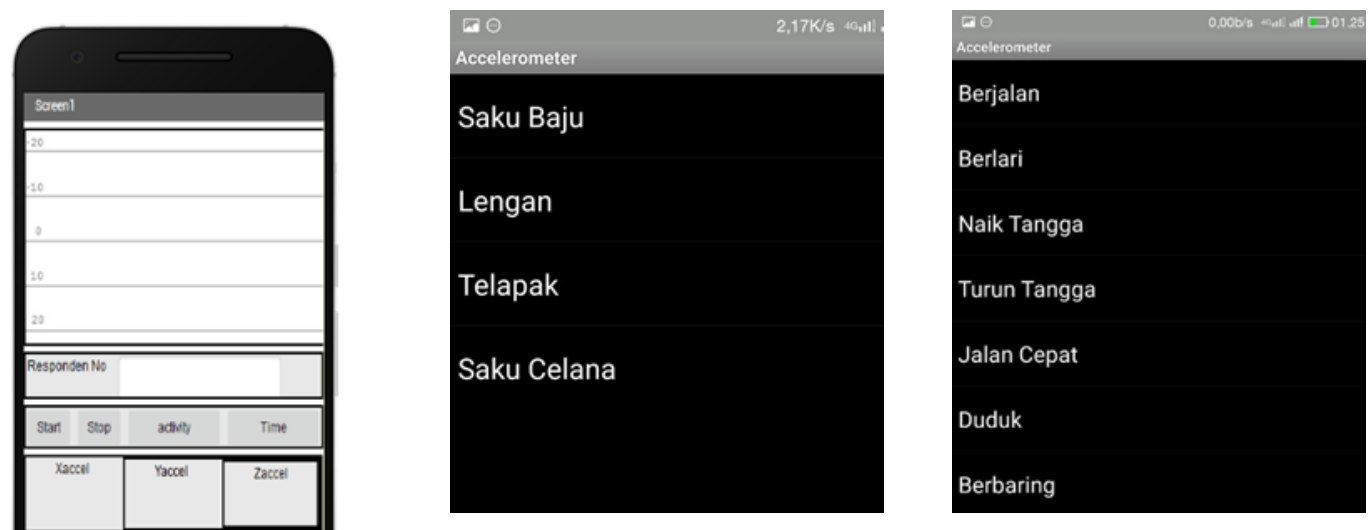

Gambar 1. Desain Perancangan Sistem (a) Tampilan Utama Aplikasi (b) Menu Pilihan Untuk memilih sensor accelerometer diletakkan pada saku celana (c) Aktivitas yang akan dipilih

Tampilan aplikasi sensor accelerometer dengan memilih posisi pada saku celana dan aktivitas berlari. Kemudian, memilih sumbu $\mathrm{x}, \mathrm{y}, \mathrm{z}$ sensor Accelerometer pada aplikasi. Selanjutnya, mengisi nomor responden kemudian klik tombol start untuk menjalankan aplikasi guna memonitoring sumbu $\mathrm{x}, \mathrm{y}$ dan $\mathrm{z}$ ketika berlari dan smartphone diletakkan pada saku celana. Responden akan menunggu sekitar 5 detik lalu berlari sesuai dengan jarak tempuh yang ditentukan apabila sudah sampai di titik jarak tempuh tekan tombol berhenti. Selanjutnya, data yang diperoleh ketika pengujian disimpan dalam bentuk file.csv dan dianalisa dengan melakukan perhitungan serta dilakukan perbandingan antara data real dengan menggunakan aplikasi sensor accelerometer.

\subsection{Flowchart Perancangan Sistem}
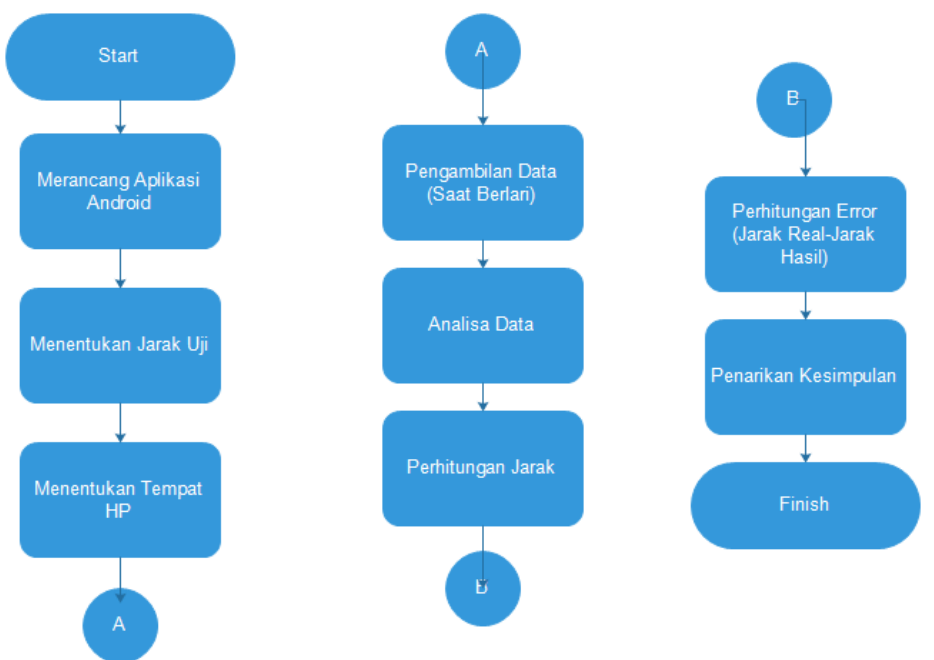

Gambar 2. Flowchart Perancangan Sistem

Pada Gambar 2 ini bertujuan untuk mendapatkan nilai $x, y$, dan $z$ yang dihasilkan oleh sensor accelerometer pada smartphone ketika pengujian. Pada analisa data yang dilakukan, setiap hasil data dari pengujian dengan jarak tempuh yang ditentukan dengan menggunakan aplikasi smartphone dan sensor accelerometer pada aplikasi maka dapat diambil data yang berbeda disetiap jarak tempuh yang telah ditentukan. metode penelitian dengan menggunakan input dari jarak uji serta menentukan posisi tempat smartphone dengan pengambilan data ketika berlari dengan mengambil sampel sebanyak 5 responden. Di awali dengan merancang aplikasi android, kemudian menentukan jarak uji yang ditentukan yaitu $5 \mathrm{~m}, 10 \mathrm{~m}, 15 \mathrm{~m}$, dan $20 \mathrm{~m}$. Setelah 
itu, menentukan letak posisi smartphone yang diletakkan di saku celana, melakukan penganbilan data dan di dokumentasikan berupa video. Selanjutnya, dilanjutkan dengan analisa data yang di dapat dari hasil pengujian aplikasi berupa file .csv yang akan dibuat grafik. Grafik diperoleh dilakukan perhitungan jarak hasil yang sudah dikalikan 0,78 $\mathrm{m}$ dari aplikasi apakah sama dengan jarak sesungguhnya. Apabila hasil di temukan selanjutnya dilakukan perhitungan presentase errornya dengan cara jarak sesungguhnya dikurangi dengan jarak hasil dibagi jarak sesungguhnya dikalikan seratus

\subsection{Rancangan Pengujian}

Pada rancangan pengujian ini dilakukan pengujian yang dilakukan kepada 5 orang responden yang melakukan aktivitas berlari. Untuk jumlah langkah dilakukan ketika pengujian. Dari hasil 5 responden tersebut akan didapatkan beberapa data yang akan diolah dan dianalisis, seperti pada Tabel 1.

Tabel 1. Tabel Perancangan Pengujian Monitoring Jarak Tempu Lari

\begin{tabular}{cccc}
\hline Aktivitas & Jarak & Responden & Jumlah Langkah \\
\hline \multirow{3}{*}{ Berlari } & 5 Meter & 5 Orang \\
& 10 Meter & 5 Orang \\
& 15 Meter & 5 Orang \\
& 20 Meter & 5 Orang \\
\hline
\end{tabular}

\subsection{Galat Persentase (Perhitungan Error)}

Perbedaan hasil pengukuran dengan pengukuran yang sebenarnya disebut kesalahan. Hasil dari suatu pengukuran belum pasti. Oleh karena itu, persentase yang digunakan untuk membandingkan kedua nilai tersebut. Galat persentase memberikan perbedaan antara nilai perkiraan dan nilai eksak sebagai persentase dari nilai eksak, dan membantu untuk melihat seberapa dekat estimasi kita terhadap nilai riil. Untuk mengetahui cara menghitung galat persentase, nilai perkiraan dan nilai eksak harus diketahui, lalu kedua angka ini dimasukkan ke dalam Persamaan 1 [3].

$$
\% \text { error }=\frac{\text { Exact Value }- \text { Aprroximate Value }}{\text { Exact Value }} \times 100
$$

Untuk menghitung galat presentase (perhitungan error) pada monitoring jarak tempuh lari ini menggunakan nilai riil jarak pengujian sebenarnya dikurangi dengan nilai hasil pada pengujian.

\section{Hasil Penelitian Dan Pembahasan}

Hasil Pengujian dan Implementasi sistem untuk monitoring jarak tempuh lari dilakukan untuk memastikan bahwa sistem yang di buat sesuai dengan kebutuhan. Implementasi perangkat lunak dan perangkat keras pada monitoring jarak tempuh lari ini dengan sensor accelerometer bertujuan untuk mengetahui hasil jarak tempuh lari responden secara real dan aplikasi dapat berfungsi dengan baik atau tidak. Pada perhitungan manual, dapat diperoleh hasil data ketika pengujian ketika aplikasi dijalankan dan dilakukan proses perekaman aktivitas berlari pada aplikasi monitoring. Sehingga, sensor accelerometer pada smartphone tersebut akan merekam nilai pada sumbu AcX, AcY dan AcZ. Sehingga, diperoleh nilai data sensor accelerometer seperti pada Tabel 2.

Tabel 2. Hasil Nilai Data Pada Aplikasi Sensor Accelerometer

\begin{tabular}{cccccccc}
\hline No & Aktifitas & $\begin{array}{c}\text { Responden } / \\
\text { Jarak }\end{array}$ & Posisi & AccX & AccY & AccZ & $\begin{array}{c}\text { Hasil } \\
\text { Aplikasi }\end{array}$ \\
\hline 1 & Berlari & $1 / 5$ meter & $\begin{array}{c}\text { Saku } \\
\text { Celana }\end{array}$ & -1.383 & 6.086 & 6.876 & 9.2863 \\
2 & Berlari & $1 / 10$ meter & $\begin{array}{c}\text { Saku } \\
\text { Celana }\end{array}$ & -0.794 & 5.801 & 7.144 & 9.2372 \\
3 & Berlari & $1 / 15$ meter & $\begin{array}{c}\text { Saku } \\
\text { Celana }\end{array}$ & 1.036 & 6.038 & 6.818 & 9.1667 \\
4 & Berlari & $1 / 20$ meter & $\begin{array}{c}\text { Saku } \\
\text { Celana }\end{array}$ & -1.051 & 6.169 & 6.653 & 9.1345 \\
\hline \hline
\end{tabular}

REPOSITOR, Vol. 2, No. 6, Juni 2020: 795-802 


\begin{tabular}{cccccccc}
\hline \hline 5 & Berlari & $2 / 5$ meter & $\begin{array}{c}\text { Saku } \\
\text { Celana }\end{array}$ & 2.262 & 5.087 & 7.249 & 9.1411 \\
6 & Berlari & $2 / 10$ meter & $\begin{array}{c}\text { Saku } \\
\text { Celana }\end{array}$ & 1.369 & 3.529 & 7.194 & 8.1296 \\
7 & Berlari & $2 / 15$ meter & $\begin{array}{c}\text { Saku } \\
\text { Celana }\end{array}$ & -1.613 & 4.175 & 6.414 & 7.8217 \\
8 & Berlari & $2 / 20$ meter & $\begin{array}{c}\text { Saku } \\
\text { Celana }\end{array}$ & -1.08 & 2.262 & 11.784 & 12.048 \\
9 & Berlari & $3 / 5$ meter & $\begin{array}{c}\text { Saku } \\
\text { Celana }\end{array}$ & -2.049 & 4.594 & 6.926 & 8.5606 \\
10 & Berlari & $3 / 10$ meter & $\begin{array}{c}\text { Saku } \\
\text { Celana }\end{array}$ & -0.110 & 4.869 & 7.627 & 9.0505 \\
11 & Berlari & $3 / 15$ meter & $\begin{array}{c}\text { Saku } \\
\text { Celana }\end{array}$ & 0.876 & 5.001 & 8.664 & 10.042 \\
12 & Berlari & $3 / 20$ meter & $\begin{array}{c}\text { Saku } \\
\text { Celana }\end{array}$ & -0.447 & 4.192 & 9.390 & 10.293 \\
13 & Berlari & $4 / 5$ meter & $\begin{array}{c}\text { Saku } \\
\text { Celana }\end{array}$ & -0.921 & 5.054 & 6.392 & 8.2011 \\
14 & Berlari & $4 / 10$ meter & $\begin{array}{c}\text { Saku } \\
\text { Celana }\end{array}$ & -1.426 & 5.272 & 8.362 & 9.9884 \\
15 & Berlari & $4 / 15$ meter & $\begin{array}{c}\text { Saku } \\
\text { Celana }\end{array}$ & -1.52 & 4.118 & 9.050 & 10.059 \\
16 & Berlari & $4 / 20$ meter & $\begin{array}{c}\text { Saku } \\
\text { Celana }\end{array}$ & 0.818 & 5.286 & 6.586 & 8.4851 \\
17 & Berlari & $5 / 5$ meter & $\begin{array}{c}\text { Saku } \\
\text { Celana }\end{array}$ & -0.215 & 5.453 & 7.692 & 9.4322 \\
18 & Berlari & $5 / 10$ meter & $\begin{array}{c}\text { Saku } \\
\text { Celana } \\
\text { Saku }\end{array}$ & -1.010 & 4.240 & 8.207 & 9.2929 \\
19 & Berlari & $5 / 15$ meter & $\begin{array}{c}\text { Celana } \\
\text { Saku } \\
\text { Celana }\end{array}$ & -0.952 & 2.049 & 8.015 & 8.3283 \\
\hline 0 & Berlari & $5 / 20$ meter & 0.098 & 5.858 & 6.986 & 9.1181 \\
\hline
\end{tabular}

Hasil pengujian yang diperoleh dari sistem monitoring menggunakan aplikasi dan sensor accelerometer akan diolah menjadi data dan perhitungan serta grafik berupa gelombang sinus. Hasil tersebut adalah nilai sumbu $x, y$, dan $z$ pada sensor accelerometer yang kemudian diproses menjadi nilai total akselerasi dan nilai ambang batas threshold. Selanjutnya dalam pengujian kali ini, dua nilai tersebut akan di visualisasikan menjadi sebuah grafik. Dalam pengujian kali ini, dua nilai tersebut akan di visualisasikan menjadi sebuah grafik. Hasil pengujian untuk dapat mendeteksi aktifitas berlari, maka ditentukan nilai ambang batas (threshold) yang telah dirancang sebelumnya berdasarkan simulasi yang dilakukan oleh 5 responden. Gambar 3, Gambar 4, Gambar 5, dan Gambar 6 berikut salah satu hasil grafik pada responden 1.

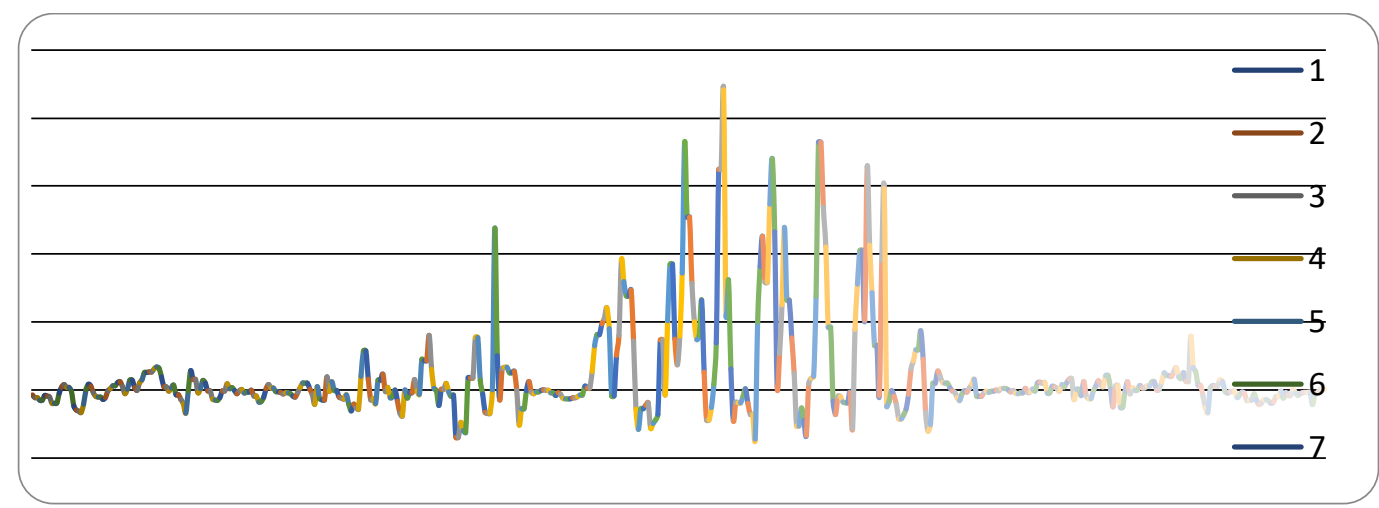

Gambar 3. Grafik Hasil Pengujian Responden 1 jarak tempuh 5 meter = 6 langkah 


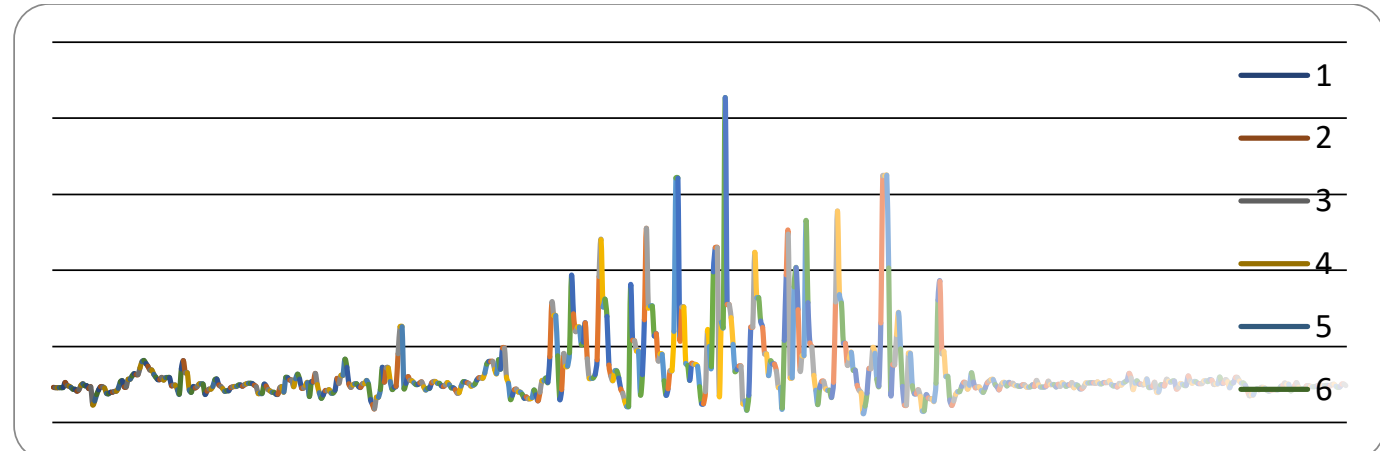

Gambar 4. Hasil Pengujian Responden 1 dengan jarak tempuh 10 meter $=11$ langkah

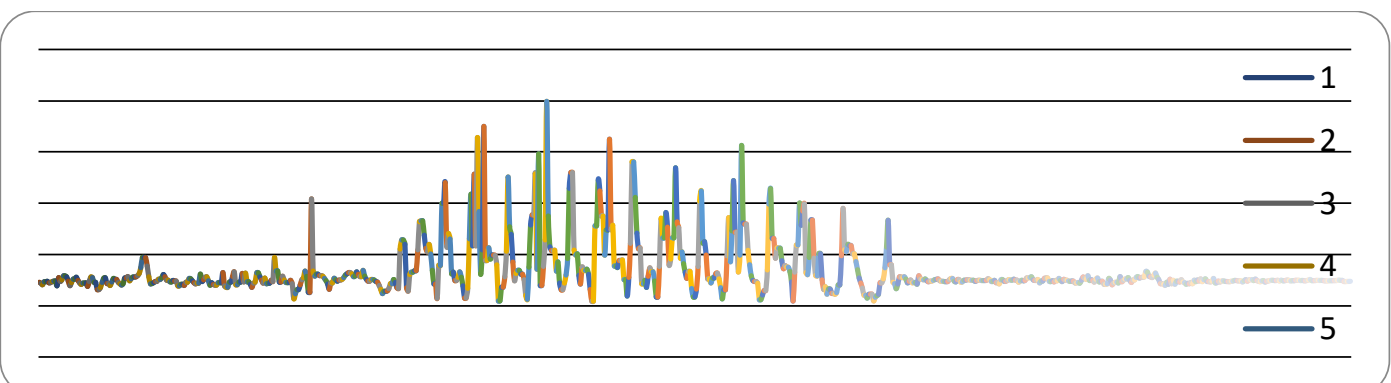

Gambar 5. Hasil Pengujian Responden 1 dengan jarak tempuh 15 meter = 18 langkah

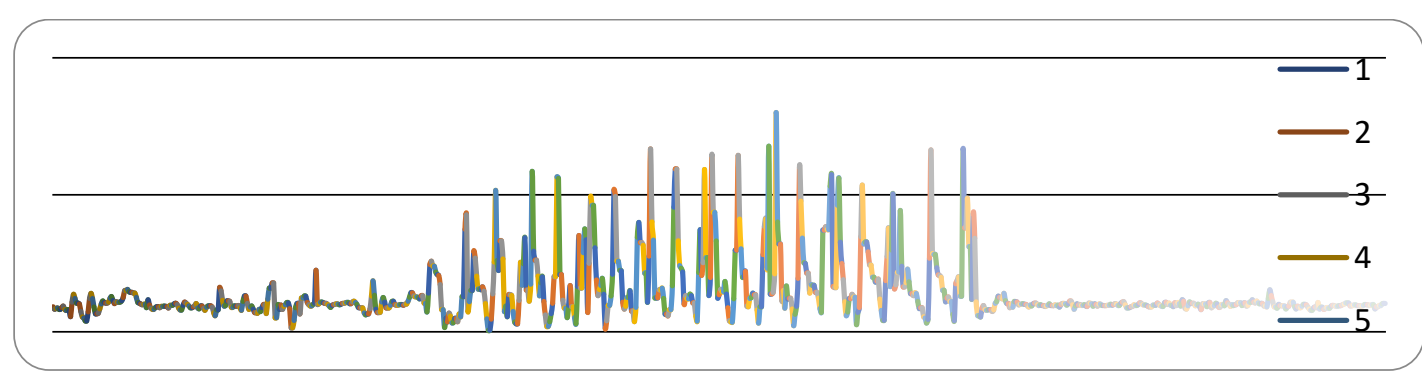

Gambar 6. Hasil Pengujian Responden 1 dengan jarak tempuh 20 meter $=23$ langkah

Pada hasil gambar diatas menjelaskan bahwa untuk menentukan langkah jarak tempuh lari, bahwa satu langkah kaki di gambarkan dengan satu gunung dan satu lembah dengan kata lain satu langkah kaki bisa di gambarkan oleh satu threshold above dan threshold below.

\subsection{Pengujian Perhitungan Data Secara Manual}

Pada penelitian monitoring ini, dilakukan pengujian untuk perhitungan rumus secara manual dengan tujuan untuk memvalidasi hasil perhitungan sistem diterapkan pada aplikasi sesuai dengan yang dirancang. Untuk memvalidasi hasil perhitungan sistem Maka dapat di hitung hasil jarak pengujian dengan Persamaan 2.

\section{a. Rumus Perhitungan Hasil Jarak Pengujian}

$$
\text { Jarak }=\text { Jumlah Langkah } * 0,78 \text { meter }
$$

b. Rumus Galat Presentase Error (\%)

$$
\text { \%error }=\frac{\text { Exact Value }- \text { Aprroximate Value }}{\text { Exact Value }} \times 100
$$




\begin{tabular}{|c|c|c|c|c|c|c|}
\hline \multicolumn{7}{|c|}{ Tabel 3. Hasil Pengujian Jarak Tempuh Lari Secara Manual } \\
\hline $\begin{array}{l}\text { Jarak } \\
\text { (meter) }\end{array}$ & $\begin{array}{c}\text { Responden } \\
1\end{array}$ & $\begin{array}{c}\text { Responden } \\
2\end{array}$ & $\begin{array}{c}\text { Responden } \\
3\end{array}$ & $\begin{array}{c}\text { Responden } \\
4\end{array}$ & $\begin{array}{c}\text { Responden } \\
5\end{array}$ & $\begin{array}{l}\text { Rata- } \\
\text { Rata }\end{array}$ \\
\hline 5 & 6 langkah & 7 langkah & 4,5 langkah & 6 langkah & 6 langkah & $\begin{array}{c}5,9 \\
\text { langkah }\end{array}$ \\
\hline 10 & 11 langkah & 12 langkah & 13 langkah & 12 langkah & 12 langkah & $\begin{array}{c}12 \\
\text { langkah }\end{array}$ \\
\hline 15 & 18 langkah & 18 langkah & 17 langkah & 13 langkah & 17 langkah & $\begin{array}{c}16,6 \\
\text { langkah }\end{array}$ \\
\hline 20 & 23 langkah & 25 langkah & 24 langkah & 22 langkah & 20 langkah & $\begin{array}{c}22,8 \\
\text { langkah }\end{array}$ \\
\hline
\end{tabular}

Hasil Perhitungan sesuai dengan rata - rata langkah hasil pengujian dengan responden 1 sampai 5 responden.

1. Hasil jarak pengujian 5 meter $=5,9 \mathrm{~m} \times 0,78 \mathrm{~m}=4,602$ meter

Galat presentase error (\%) $\quad=\frac{5-4,602}{5} \times 100=7,96 \%$

2. Hasil jarak pengujian 10 meter : $12 \mathrm{~m} \times 0,78 \mathrm{~m}=9,36$ meter Galat presentase error (\%) : $\frac{10-9,36}{10} \times 100=6,4 \%$

3. Hasil jarak pengujian 15 meter : $16,6 \mathrm{~m} \times 0,78 \mathrm{~m}=12,948$ meter Galat presentase error (\%) : $\frac{15-12,948}{15} \times 100=13,68 \%$

4. Hasil jarak pengujian 20 meter : $22,8 \mathrm{~m} \times 0,78 \mathrm{~m}=17,784$ meter Galat presentase error (\%) : $\frac{20-17,784}{20} \times 100=11, \%$

\section{Kesimpulan}

Dari hasil kesimpulan yang telah diperoleh bahwa Data yang diperoleh dari jarak tempuh lari hasil pengujian dengan 5 responden hampir sama dengan data real. Dari jarak pengujian 5 meter diperoleh hasil galat presentase error sebanyak 7,96\%. Jarak 10 meter diperoleh sebanyak $6,4 \%$. Jarak 15 meter diperoleh $13,68 \%$ meter. Selanjutnya, jarak 20 meter yaitu $11 \%$.

Sedangkan, Keuntungan dari aplikasi MIT APP Invertor, penulis dapat menganalisa data jarak tempuh lari dari sensor accelerometer dan membandingkan dengan jarak tempuh lari yang sebenarnya. Hasil monitoring jarak tempuh lari sangat bergantung pada gaya berlari dan posisi hp. Dari aplikasi yang digunakan dapat dilakukan pengembangan aplikasi monitoring jarak tempuh secara real time sebagai pembaharuan sistem yang lebih baik.

\section{Referensi}

[1] M. D. A. J. J. P. R. G. P. Widya, "Belajar berlatih gerak-gerak dasar atletik dalam bermain," 2011.

[2] S. Norhabibah, K. Andhyka, and D. J. J. Risqiwati, "Rancang Bangun Sistem Monitoring Deteksi Jatuh untuk Manula dengan Menggunakan Accelerometer," vol. 1, no. 1, pp. 43-52, 2016.

[3] D. A. FITRIANI, "Rancang Bangun Sistem Monitoring Langkah Kaki Dengan Sensor Mpu6050 Berbasis Android," University of Muhammadiyah Malang, 2016.

[4] S. N. Ubay, "Pengembangan Sistem Monitoring Langkah Kaki Dengan Sensor Mpu6050 Untuk Menghitung Jumlah Penurunan Berat Badan Berbasis Android," University of Muhammadiyah Malang, 2018.

[5] B. Aryatama, "Pengembangan Alat Analisis Kecepatan Lari Berbasis Accelerometer," Universitas Negeri Yogyakarta, 2015

[6] L. E. Sunaryo, "Pembuatan Aplikasi" Let's Healthy" Memanfaatkan Accelerometer Di Smartphone Android," University of Muhammadiyah Malang, 2015.

[7] I. M. Nusaman, Nilai Ambang Batas dan Standarisasi di Bidang Keteknikan, 2012. [Online]. Available.

[8] A. A. Candra, "Aplikasi Penghitung Langkah (Pedometer) Berbasis Android," 2015.

[9] M. I. Khalif, "Pengembangan Sistem Penghitung Langkah Kaki Hemat Daya Berbasis Wemos D1 mini," Universitas Brawijaya, vol. vol.2, p. 19, 2018. 
REPOSITOR, Vol. 2, No. 6, Juni 2020: 795-802 